\title{
Spatiotemporal analysis of dry spells for support to agriculture adaptation efforts in the Sudano-Sahelian region of Nigeria
}

\author{
Mansur Matazu Bako ${ }^{1}$. Sani Abubakar Mashi ${ }^{1} \cdot$ Ahmad Abdullahi Bello $^{1} \cdot$ James $_{\text {ljampy Adamu }}{ }^{1}$
}

Received: 19 February 2020 / Accepted: 30 June 2020 / Published online: 6 July 2020

(c) Springer Nature Switzerland AG 2020

\begin{abstract}
Change in rainfall pattern is one of the observed and projected impacts of climate change across the Sudano-Sahelian region of Nigeria. As a consequence, agricultural practices and water resources would highly be impacted. In this study, 38-year (1981-2018) daily rainfall data observed over 13 meteorological stations distributed across the Sudano-Sahelian region of Nigeria were used to investigate the spatial distribution and long-term trend of dry spells. Four dry spell indices defined as frequency of dry spell (FDS), total dry spell (TDS), maximum dry spell (MxDS) and mean dry spell (MDS) were examined monthly, focusing on the wet season (May-October). The results revealed a positive gradient in TDS, MxDS and MDS from southwest to northeast. In contrast, FDS revealed a negative southwest to northeast gradient. The highest TDS, MxDS and MDS days are found during wet season onset (May-June) and end of season (September-October), while the lowest days are found at the peak of the rainy season (July-August). Furthermore, an analysis of long-term trend using the nonparametric Mann-Kendall statistical test revealed a prevailing decline in TDS, MxDS and MDS from May to October. This could enhance agricultural activities over the region. However, a significant increase in dry spell is evident in Gombe (May-June) and Kaduna (June). This could pose a great threat to agricultural practices over these regions if it persists.
\end{abstract}

Keywords Dry spell · Drought $\cdot$ Support of agriculture adaptation $\cdot$ Sudano-Sahel region $\cdot$ Nigeria

\section{Introduction}

Drought is the major disaster that affects the SudanoSahelian region of Nigeria [1], it has occurred quite frequently in the past years over this region [2-5], and it is primarily due to insufficient rainfall caused by prolonged dry spells [6]. Consequently, insufficient rainfall has devastating impacts on Nigeria's economy as poor agricultural practices, low agricultural yield and poverty have been directly linked to it [7]. The effects of drought and dry spells to livestock are also extreme, and it results in longdistance migration of herders in search of water and green pasture for their livestock [8].
Rainy season in Nigeria is highly variable in both spatial and temporal scales [9-11]; it begins in February over southern Nigeria [12] and June over the northernmost parts [12, 13]; however, late May to late October and early July to early September were found to be optimum for crop production over the southern and northern parts of Nigeria, respectively [14].

An increase in extreme temperature, heatwaves and changes in rainfall patterns are some of the impacts of global warming that were detected over different climatic zones in Nigeria $[9,15,16]$. Although there were reports of rainfall recovery from the dry periods of the 1970s and 1980s over West Africa [17], this wasn't pronounced until late 1990s over the Sudano-Sahelian region of Nigeria [13].

$\square$ Ahmad Abdullahi Bello, ahmadbels@gmail.com | ${ }^{1}$ National Weather Forecasting and Climate Research Center, Nigerian Meteorological Agency, Abuja, Nigeria. 
Similarly, this is evident in most parts of the Guinea Coast, although trends are not significant. Also, a recent analysis of changes in West African summer monsoon rainfall showed a significant increase in the Sahel [18]. Specifically, over the Sudano-Sahelian region of Nigeria, a significant increase in rainfall amount in recent decades has been reported by several studies in most parts [19-22]. Usman et al. [22], for example, reported an increase in rainfall amount as well as length of the rainy season over the Sudano-Sahelian region of Nigeria using both groundbased observation and satellite products. The results indicated rainfall increase, mostly marked from August to October. Furthermore, an earlier onset of the rainy season coupled with an increase in mean annual rainfall would prevail over this region in the future $[23,24]$. These changes in rainfall patterns will equally result in changes in the characteristics of dry spells [25].

Various studies have been performed on dry spells over different regions of the World. Kebede et al. [26], for instance, found no significant changes in dry spell, onset, cessation and duration of rainfall in Baro-Akobo river basin of Ethiopia, while up to $50 \%$ increase in dry spell frequency was reported in Botswana [27]. Additionally, there has been a significant decrease in number of dry days over the Sahel in contrast to a significant increase in number of dry days over the Guinea Coast [18]. Studies over Nigeria include Ayanlade and Ojebisi [8] which showed an increase in dry spell intensity in the Guinea Savannah region of Nigeria. Another study by Ayanlade et al. [11] revealed that dry spells have a high monthly variability over southwest Nigeria and further concluded that there is a high probability of dry spells exceeding 3 and 5 days during the growing season (March-October) over this region.

Furthermore, Sawa and Adebayo [28] using daily rainfall and crop yield data for the period 1960-2009 examined the impact of dry spells on some selected crops in northern Nigeria. The study identified 10 days dry spell in August and the total dry spell during the growing season to be the most critical factors affecting crop yields over this region. Also, according to Hassan et al. [7] the practice of sowing seeds before the first rainfall is a common practice among farmers in northern Nigeria, yet, dry spell of approximately 12-15 days after onset of the rainy season is of great concern to farmers as it causes crop failures and thereafter insufficient yield. Therefore, accurate prediction of onset and cessation of the rainy season, as well as duration and frequency of dry spells, is necessary for proper planning and decision making, especially in agriculture and water resource management $[13,22,29]$. This can only be achieved through proper understanding of the spatial distribution and temporal variability of dry spell in any particular region [30].
Previous studies performed on dry spells over the Sudano-Sahelian region of Nigeria have either used a limited number of stations or satellite-derived products $[13,22]$. This study, therefore, aims to investigate the spatiotemporal distribution of dry spell over the SudanoSahelian region of Nigeria using a relatively good network of ground-based stations. We adopted dry spells to be a sequence of days each with rainfall below $1 \mathrm{~mm}$ [31], a day with rainfall equal or above $1 \mathrm{~mm}$ breaks the dry spell, and another count begins when rainfall falls below that threshold. Four indices defined as frequency of dry spell (FDS), total dry spell (TDS), maximum dry spell (MxDS) and mean dry spell (MDS) were examined, and these have been previously used to study drought and dry spells in other regions [32-34]. The analysis was performed for each month during the wet season (May-October) [35] because this finer temporal scale is more advantageous, especially to crop production [36].

\section{Materials and methods}

\subsection{Data and study area}

Sudano-Sahelian region is a semiarid zone that coincides with the northern part of Nigeria from latitude $10^{\circ} \mathrm{N}$ to $14^{\circ} \mathrm{N}$ (Fig. 1). Its lowest point is around Yelwa in Kebbi State which is about $113 \mathrm{~m}$ above mean sea level, while the highest point is around south of Bauchi and west of Kaduna which is over $1000 \mathrm{~m}$ above mean sea level (Fig. 1). The climate of this region is highly variable; during the dry season (November-March), the weather is dominated by dusty, dry and cold Harmattan winds that originate from the Sahara desert. The wet season occurs from May to October, and it is dominated by moist southwesterly winds that originate from the ocean which brings abundant moisture inland of the country. This region receives the least amount of rainfall compared to other places in Nigeria, with a mean annual rainfall of about $610 \mathrm{~mm}$ [13]. The major occupation of the inhabitants of this region is farming and rearing of animals which makes rainfall extremely important and fluctuation in its characteristics worrisome.

This study used daily rainfall data obtained from 13 synoptic stations distributed across the Sudano-Sahelian region of Nigeria (Fig. 1). These records come from the 1981 to 2018 period and were provided by the Nigerian Meteorological Agency (NiMet). These records are not without missing values; however, all stations used here have at least $95 \%$ complete records, and missing values were filled with 38-year daily averages. Furthermore, a homogeneity test was performed by using $\mathrm{RH}$ test software [37] and all climatic series were found to be homogenous. 
Fig. 1 Location of the meteorological stations and elevation (in meters) of the study area (Sudano-Sahelian Nigeria)

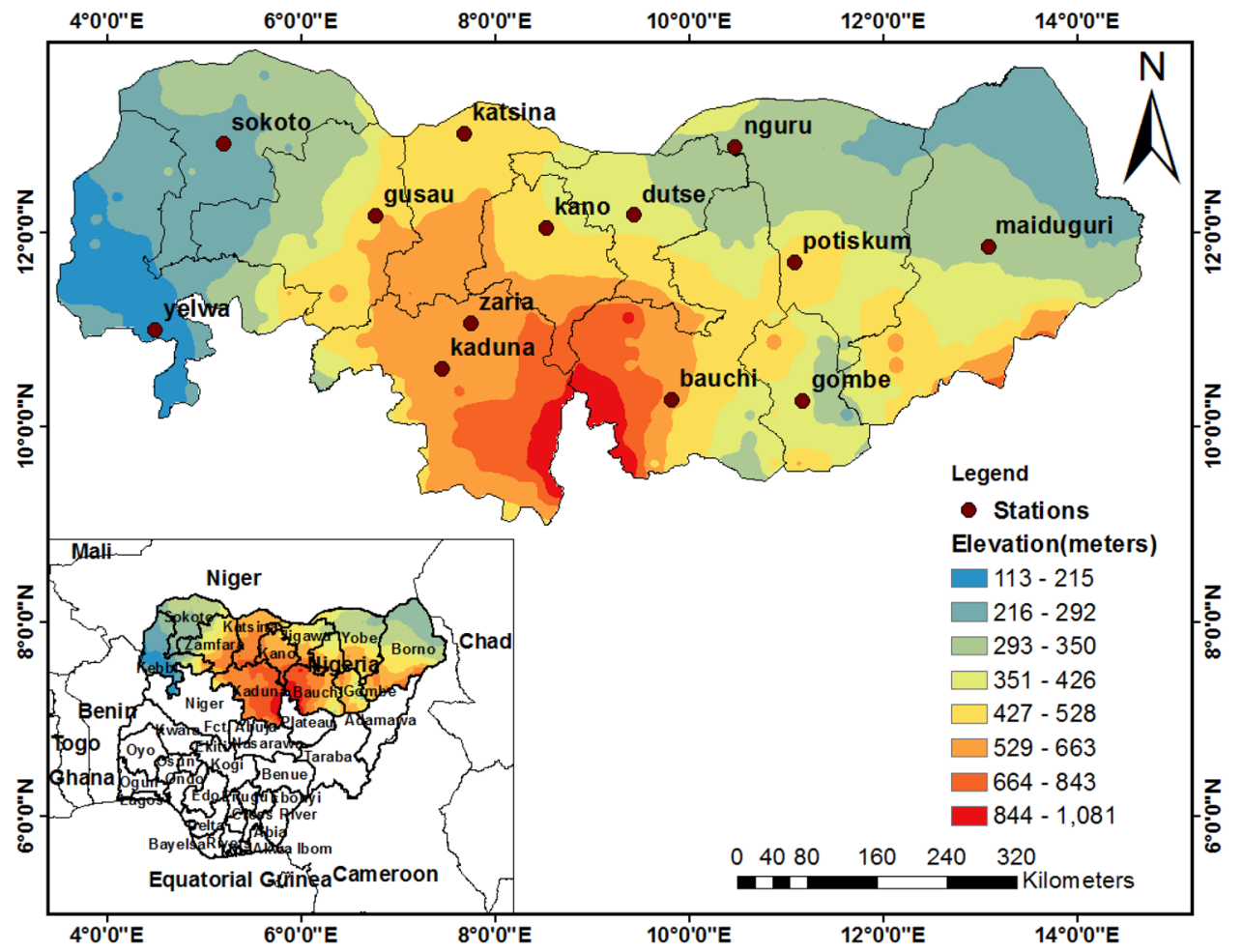

This is supported by [38] which employed 11 out of the stations used in this study from 1981 to 2015.

\subsection{Method}

In this study, we adopted dry spell to be a sequence of days with rainfall below $1 \mathrm{~mm}$. Dry spell indices (Table 1) were calculated monthly from May to October, such that a dry spell that started at the end of May and continued for a few days in June will be considered as two separate events, one for each month. Furthermore, spatial maps were produced using the inverse distance weighted (IDW) method in ArcGIS 10.5. IDW is a spatial interpolation method that assumes the closest values surrounding a location of interest to have more influence in predicting its values [39]. An analysis to detect trend was performed using the Mann-Kendall test [40, 41]. The Mann-Kendall test being a nonparametric statistical test is widely used to test for the existence of a monotonic trend in climatic variables; it is very effective given the long sequence of data available in this study and is robust in the sense that it takes care of missing values and no prior assumption on the distribution of the dataset is required. More information on the Mann-Kendall test can be found in $[40,41]$. The Mann-Kendall test was performed using the Kendall package [42] in R software [43]. The significance of the trend was determined at a $95 \%$ confidence level.

\section{Results and discussion}

\subsection{Spatial distribution of dry spell}

The monthly spatial distribution of total dry spell (TDS), maximum dry spell (MxDS), mean dry spell (MDS) and frequency of dry spell (FDS) on averaged over 38 years (1981-2018) is displayed in Figs. 2, 3, 4 and 5. The spatial distribution of TDS over the Sudano-Sahel region follows a northeast to southwest orientation (Fig. 2); this remains unchanged from May to October as the number of days

Table 1 Definitions of the four dry spell indices used

\begin{tabular}{lllll}
\hline No. & Index name & Definition & Unit \\
\hline 1 & FDS & Number of occurrence of dry spell in each month, averaged across years (1981-2018) & Events \\
2 & TDS & Total dry spell length for each month, averaged across years (1981-2018) & Days \\
3 & MxDS & Maximum dry spell length for each month, averaged across years (1981-2018) & Days \\
4 & MDS & Mean dry spell length for each month, averaged across years (1981-2018) & Days \\
\hline
\end{tabular}


Fig. 2 Total dry spell (TDS) for: a May; b June; c July; d August; e September; $\mathbf{f}$ October
Fig. 3 Maximum dry spell (MxDS) for: a May; b June; c July; d August; e September; $\mathbf{f}$ October

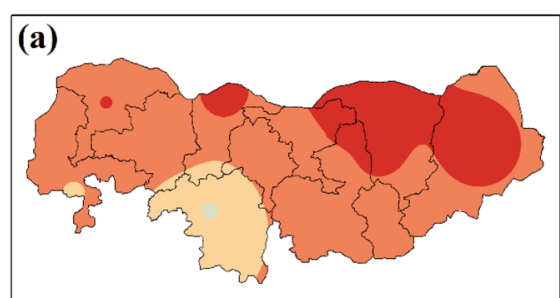

\section{(b)}

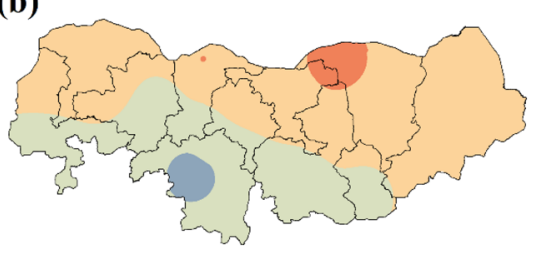

(c)

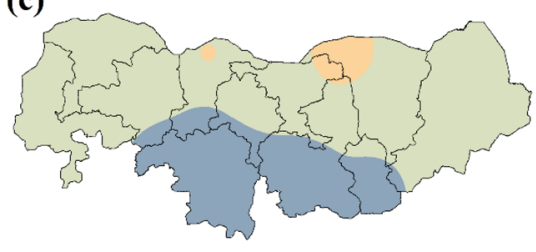

(d)
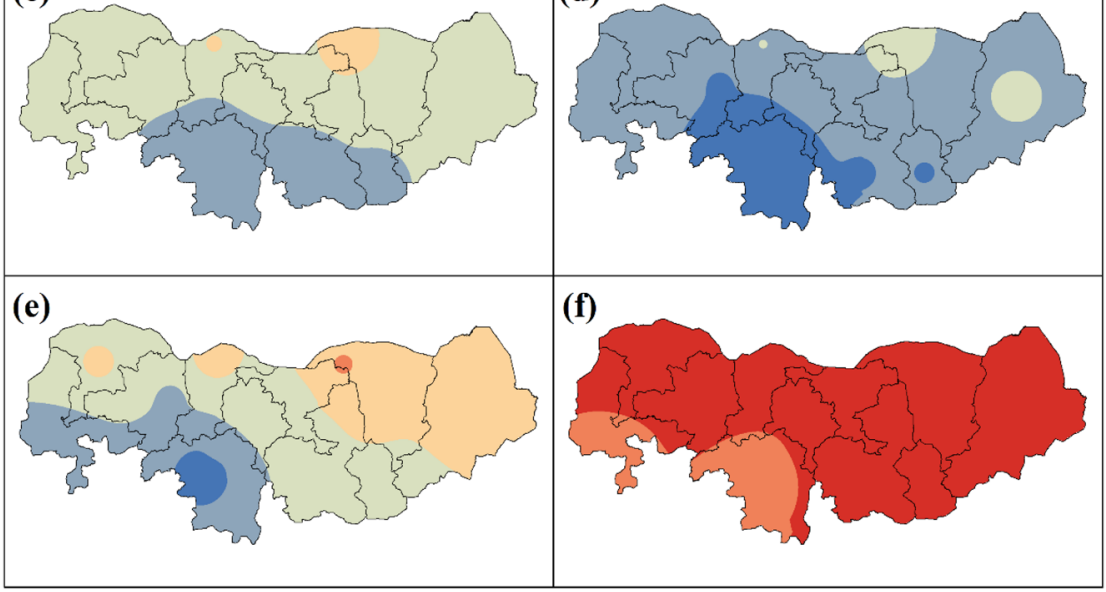

Legend

Days

$13.3-16$ $16.1-18.9$ $19-21.7$

21.8 - 24.5

$24.6-27.3$

$27.4-30.1$

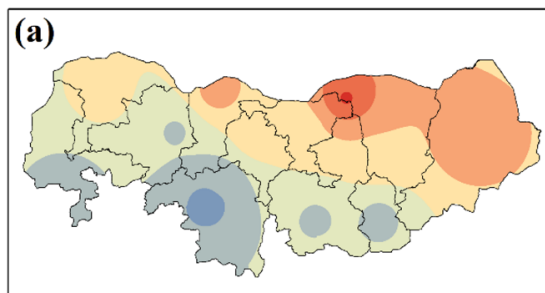

(b)
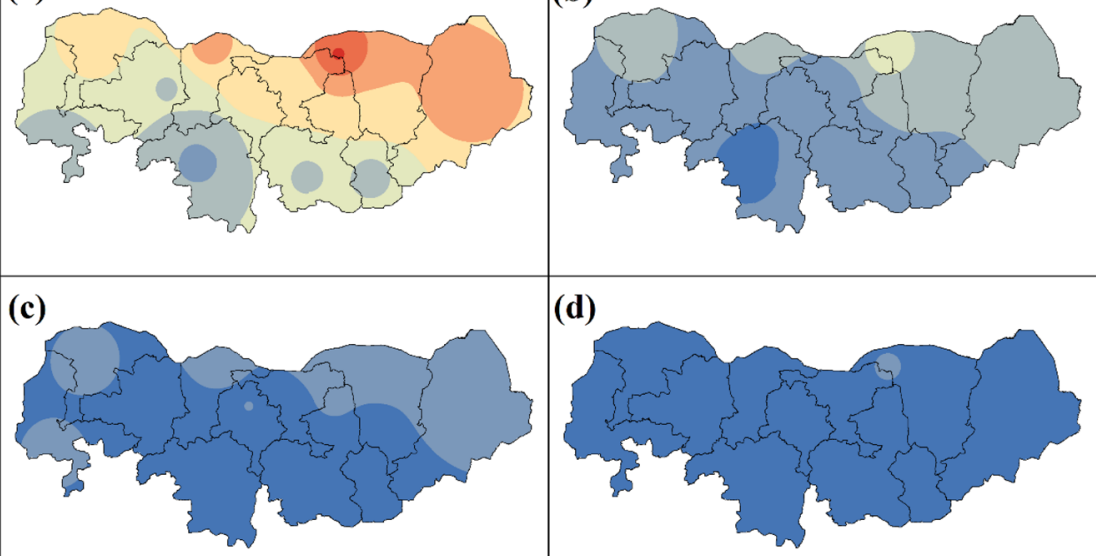

(d)
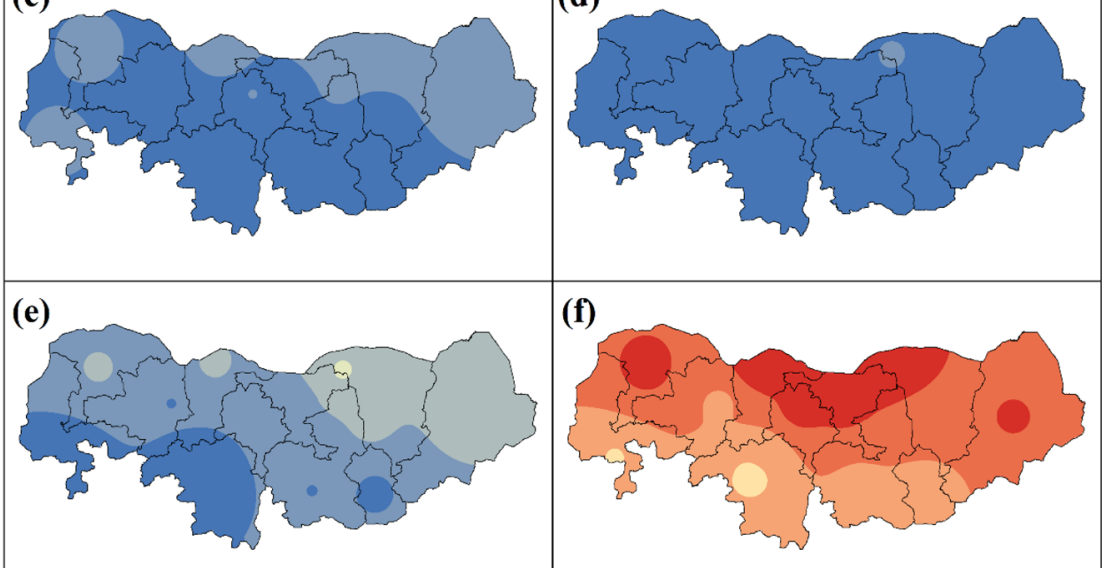

(f)

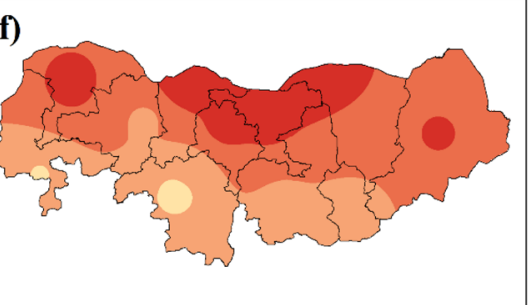

egend

Days

$3.6-6.4$

$6.5-9.3$

$9.4-12.2$

$12.3-15.1$

$15.2-17.9$

$18-20.8$

$20.9-23.7$ reduced gradually from northeast to southwest. It ranges from 19 to 30 days in May (Fig. 2a) and decreases gradually until it reaches the lowest point in August which ranges between 13 and 21 days(Fig. 2d), after which it retrogresses, reaching the highest peak of 25-30 days in October (Fig. 2f) October.

Similarly, the spatial distribution of maximum dry spell (MxDS) exhibited a northeast-southwest gradient 
Fig. 4 Mean dry spell (MDS) for: a May; b June; c July; d August; e September; $\mathbf{f}$ October

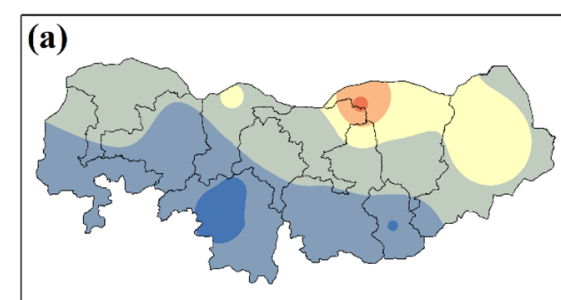

\section{(b)}
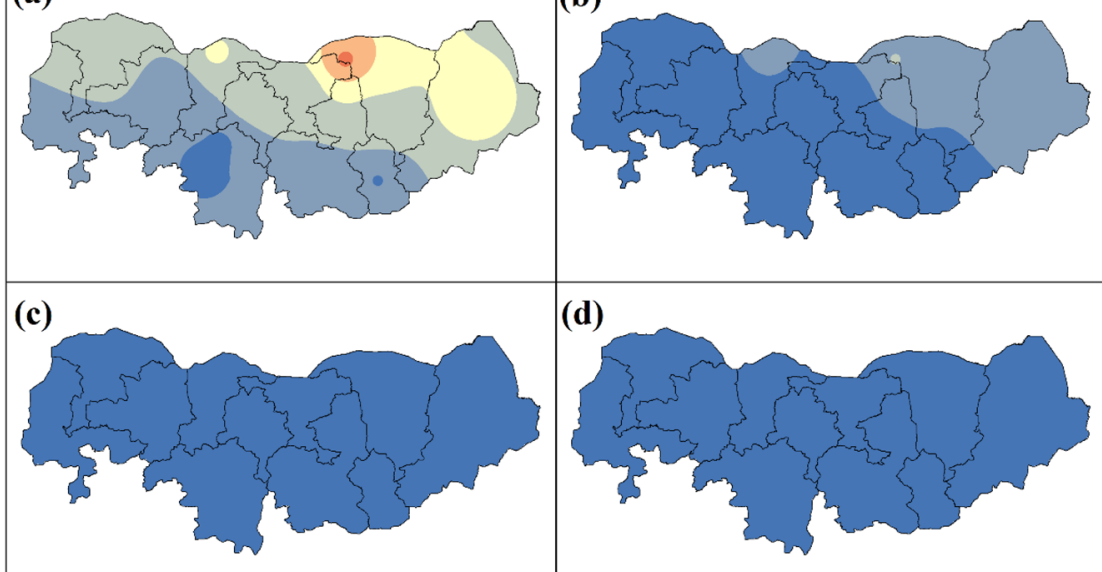

(d)
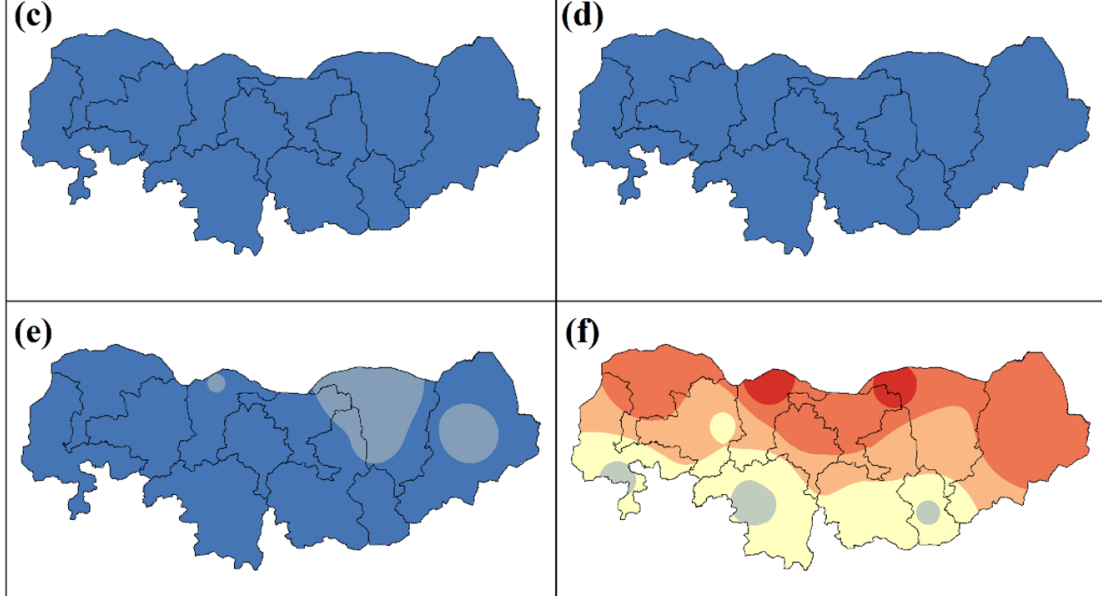

(f)

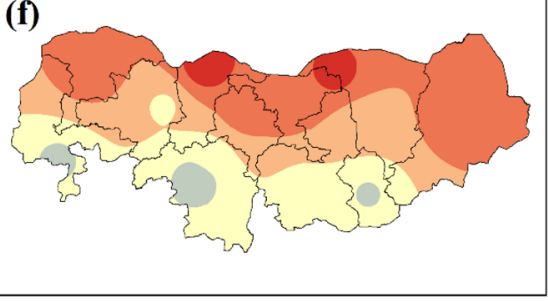

Legend

Days

$1.7-4.7$

$4.8-7.7$

$7.8-10.7$

$10.8-13.6$

$13.7-16.6$ $16.7-19.6$

Fig. 5 Frequency of occurrence of dry spell (FDS) for: a May; b June; c July; d August; e September; f October

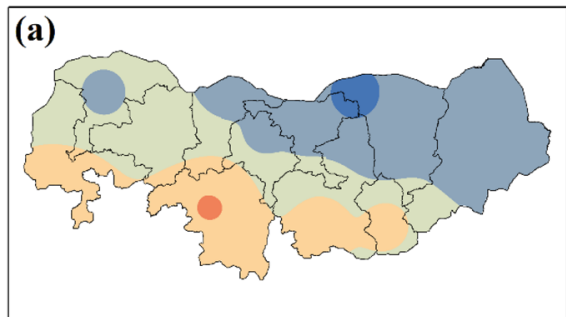

(b)

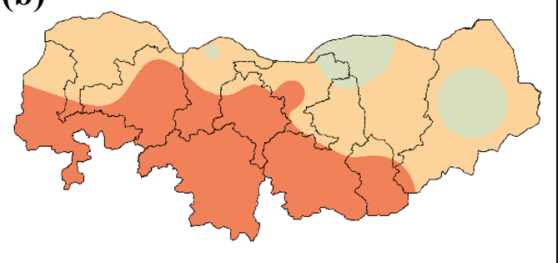

(c)

(d)
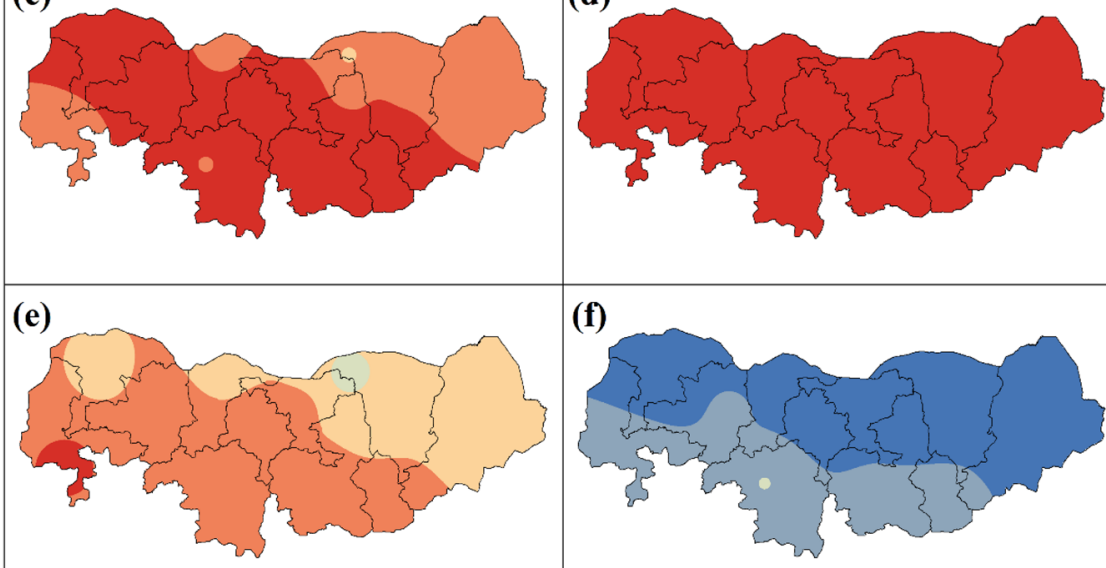

(f)

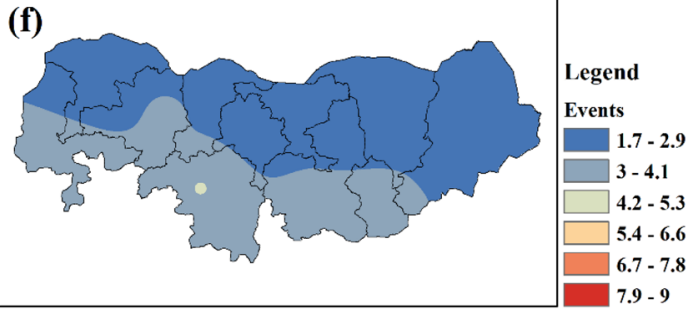

where the number of MxDS days was relatively higher to the northeast. The highest MxDS length occurred in May (6-27 days) as shown in Fig. 3a and gradually declined to 3-9 days in August (Fig. 3d). This is supported by the findings of Umar et al. [13] that medium (8-14 days) to long ( $>15$ days) MxDS occur mostly in May, June and July over the northernmost parts, precisely in Sokoto, Katsina, Dutse, Nguru and Maiduguri. It is worth mentioning that Nguru station recorded the highest length TDS and MxDS in all months during the analyzed period 
(May-October); this is because it has the shortest length of rainy season in Nigeria [12]. Mean dry spell (MDS) also depicts a comparable spatial distribution with TDS and MxDS, although the length of days was relatively lower (approximately 2-23 days) as shown in Fig. 4 . The wide range in length of TDS, MDS and MxDS (Figs. 2, 3, 4) during the onset months (May and June) when compared to the rainy season peak (July and August) and end of the season (September and October) could be linked to the high variability of rainy season onset over this region which is characterized by scattered rains produced due to local conditions during the onset [12].

The northeast-southwest gradient exhibited by TDS, MxDS and MDS is not unusual as the northeastern part of the Sudano-Sahel falls within the Sahel ecological zone which receives the least amount of rainfall over Nigeria [13], and this pattern is resulting from the northeastward advancement of rainfall during the onset [12]. Furthermore, the decline in TDS, MxDS and MDS from May to August after which an increase is noticed from September to October may be attributed to the opposite pattern demonstrated by monthly rainfall (May-October) over this region [9], and this is controlled by oscillation of the inter-tropical discontinuity (ITD) from south to north during the rainy season. The ITD reaches its peak of about $22^{\circ}-25^{\circ} \mathrm{N}$ in August, after which it begins to retreat [13]. This is in line with Froidurot and Diedhiou [31] who using TRMM 3B42 daily data found a close relation between spatiotemporal variability of dry spell and that of the West African monsoon.
In contrast to TDS, MxDS and MDS, the spatial distribution of frequency of dry spell (FDS) shows a southwest-northeast gradient in all months under study except for August (Fig. 5). Higher values of FDS were found in the southwest and range from 2 to 9 events in May and June. In July, it ranges from 5-9 events to 7-9 events in August. A decline is noticed in September to 4-9 events and further a decline to 2-47 events in October. The lower FDS in onset (May-June) and cessation (September-October) is as a result of higher dry spells in these months (Figs. 2 and 3). Also, higher FDS during the peak of the season (July-August) is attributed to a more frequent alternation between wet and dry spells. The inverse relationship between length and frequency of dry spell was also reported by Froidurot and Diedhiou [31].

Prolonged dry spell during the rainy season onset (May-June) could entirely result in crop loss [13]. Although the occurrence of medium-long dry spells toward the end of the rainy season (September-October) (Fig. 3e and $f$ ) may not be as detrimental as during the onset, it could also result in a similar effect, due to insufficient moisture required for maturity of some crops. It should be noted, however, that medium-long dry spells could as well occur at the peak of the rainy season (July-August), but this is not captured here as the length of MxDS was averaged across years (1981-2018).

\subsection{Temporal variation of dry spell}

The results of the Mann-Kendall statistical test applied to detect monotonic trends in TDS, MxDS, MDS and FDS are
Fig. 6 Trend of total dry spell (TDS) for May-October
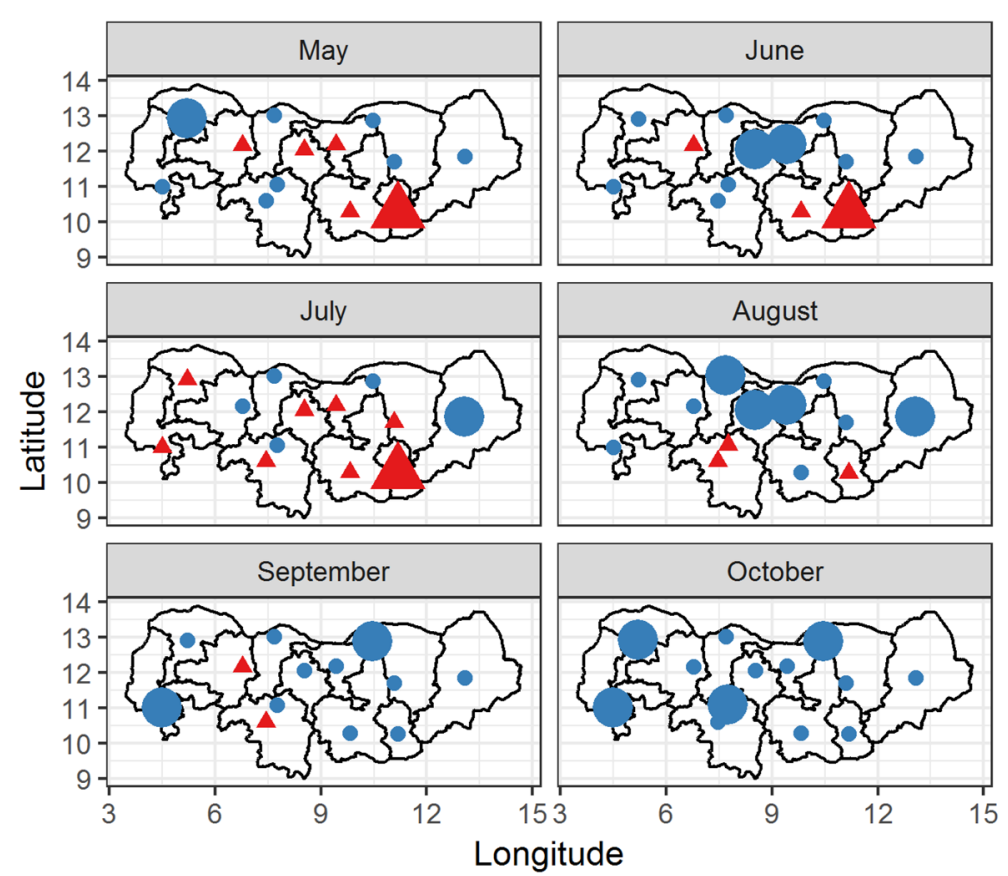

significance

- Notsignificant Significant

trend

- Negative

- Positive 
Fig. 7 Trend of maximum dry spell (MxDS) for May-October
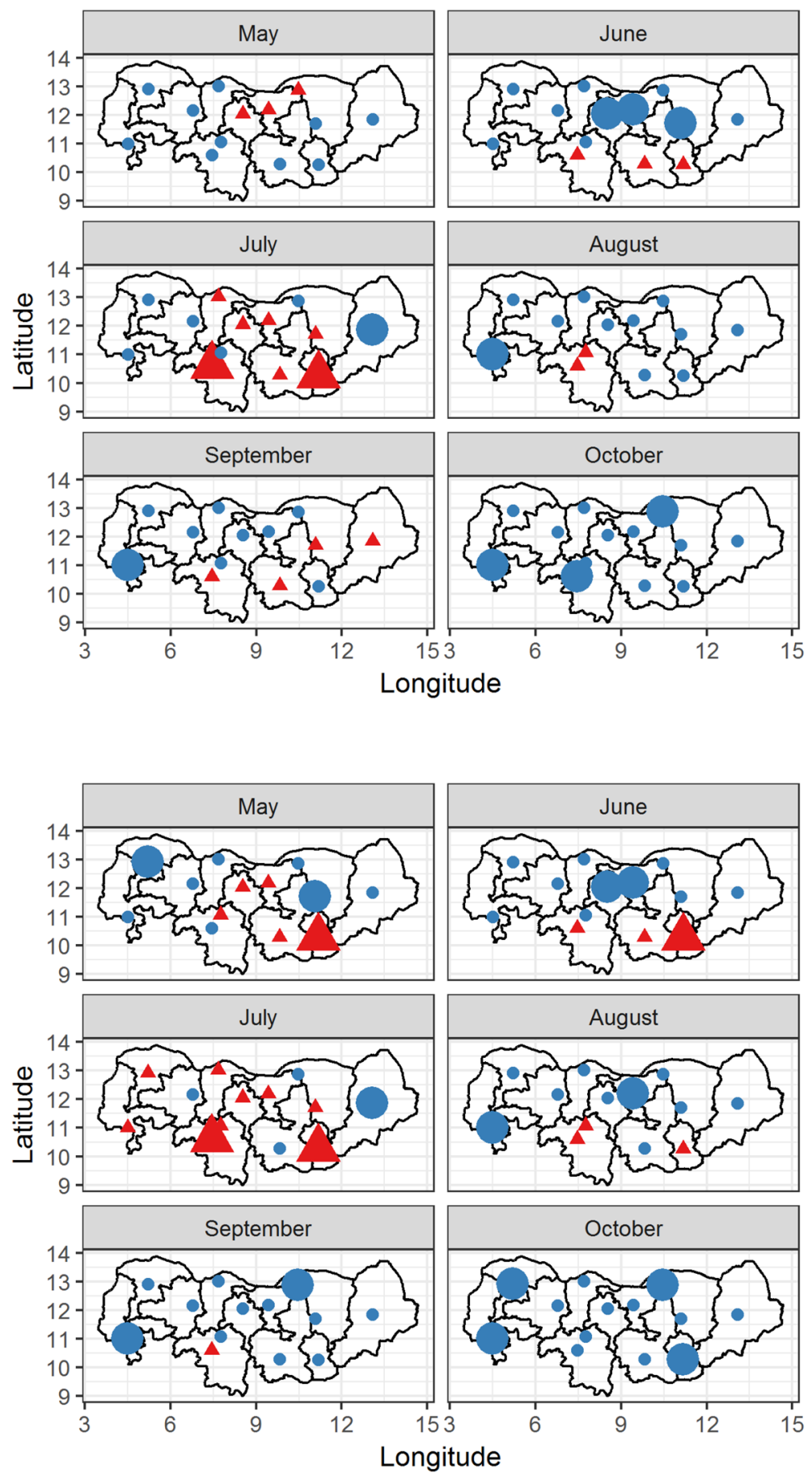

significance

- Notsignificant

Significant

trend

- Negative

- Positive
Fig. 8 Trend of mean dry spell (MDS) for May-October presented in Figs. 6, 7, 8 and 9; blue (red) color represents a negative (positive) trend. Also, the sizes represent significance. Large (small) shapes represent significant (not significant) trends. Additionally, the trend values (significant trends in bold) are presented in Table 2. These results are presented monthly for the period 1981-2018. A combination of positive and negative trends in TDS is detected over the study region from May-September (Fig. 6). Majority of these trends are negative with a few stations having a significant negative trend. In October, a negative trend is observed in all stations, with Sokoto, Yelwa, Zaria and Nguru having significant negative trends. However, a significant positive trend is only seen in Gombe in May, June and July, and this could indicate a tendency toward late onset of the rainy season.

Similar to TDS, the spatial distribution of trends of MxDS and MDS is not homogenous, with a good number of stations having a negative trend, some of which are 
Fig. 9 Trend of the frequency of dry spell (FDS) for MayOctober
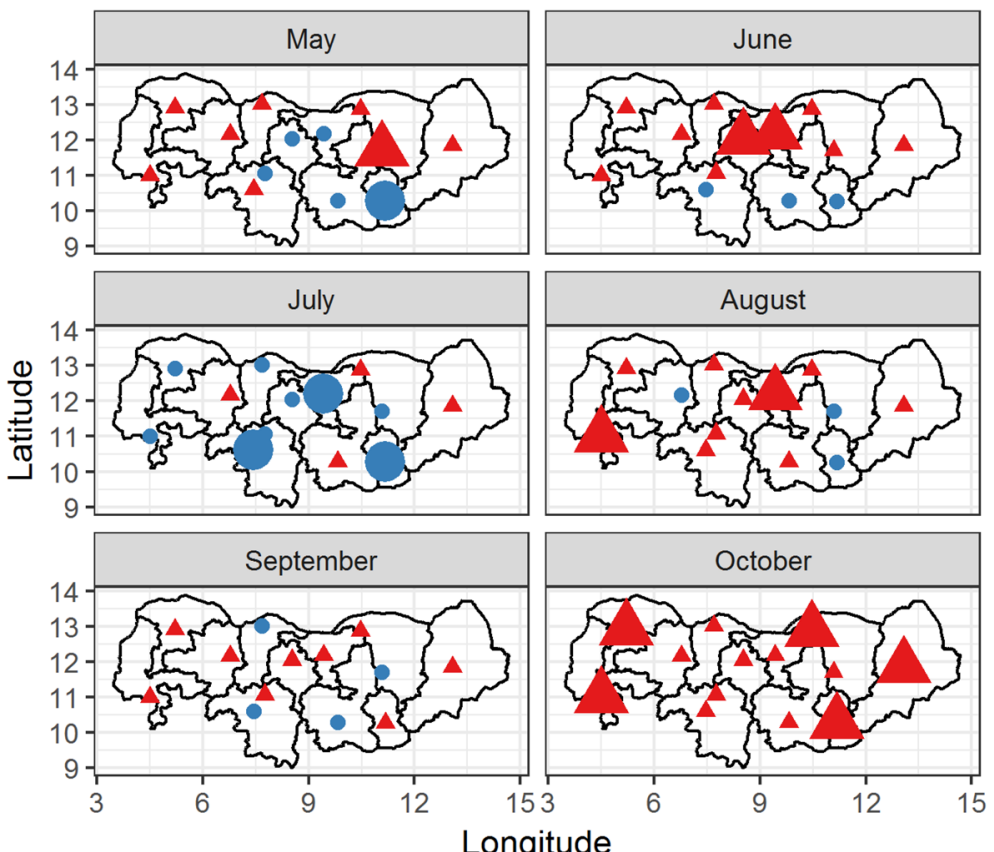

significance

- Notsignificant Significant

trend

- Negative

^ Positive
significant(Figs. 7 and 8). Only Gombe and Kaduna showed a significant positive trend in MxDS in July (Fig. 7), while Gombe showed a significant negative trend of MDS in May, June and July in addition to Katsina in July (Fig. 8). This implies an increase in wet days over the Sudano-Sahelian region except for Gombe.

This is in line with recent studies that found a significant increase in monthly rainfall from May to October as well as annual/seasonal rainfall over most parts of SudanoSahel $[22,44]$. Moreover, the negative trend in TDS, MxDS and MDS (Table 2) over the entire study region in October supports the claims toward a wetter end of season made by previous studies $[17,22,44]$ which is characterized by longer wet spell duration and more extreme rainfall events [17]. From Fig. 9, majority of the stations in the SudanoSahelian region exhibited a positive FDS except in July. Most of the stations depict a negative trend in FDS out of which Kaduna, Dutse and Gombe are significant. In contrast to TDS, MxDS and MDS (Figs. 6, 7, 8), all the stations were found to have a positive FDS trend in October, with 5 stations showing a significant negative trend (Fig. 9).

\section{Conclusion}

Information on dry spell alongside other rainfall-related variables such as rainfall onset and cessation dates, length of the growing season and seasonal rainfall amount is highly needed for agricultural planning and adaptation strategies. In this study, an analysis of the spatiotemporal distribution of dry spells in the Sudano-Sahelian region of Nigeria was performed on a monthly scale from May to October over a 38-year (1981-2018) period. Dry spells, defined as the number of consecutive days with rainfall below $1 \mathrm{~mm}$, were studied using four indices: total dry spell (TDS), maximum dry spell (MxDS), mean dry spell (MDS) and frequency of dry spell (FDS). The spatial distribution of TDS, MxDS and MDS showed a positive gradient from southwest to northeast, and the longest dry spells were found to the northeast and shortest to the southwest, assenting that the northeastern part is drier. On the other hand, FDS depicted an opposite pattern, except in August where the highest FDS was observed in the northern part over Dutse and Katsina. Furthermore, a combination of negative and positive trends in TDS, MxDS and MDS was evident across the study region from May-September, yet majority of the stations reported a negative trend, some of which are significant. This implies dry spell is decreasing predominantly over this region. However, significant increases in TDS and MDS were found in Gombe from May to July and a significant increase in MDS over Kaduna in July. Furthermore, a significant increase in MxDS was found in Gombe and Kaduna in July. Therefore, supplementary irrigation is recommended for sustainable agriculture during this period over these locations. All the indices concerning dry spell lengths (MDS, MxDS and TDS) exhibited a negative trend over the whole region in October, some of which are significant. This is in agreement with previous studies that reported a rainfall increase in October over the Sudano-Sahelian region [22, $35,44]$. Nonetheless, the results presented here may differ when a different threshold is used to determine dry 
Table 2 Trends of monthly dry spell indices (Kandall's tau statistic)

\begin{tabular}{|c|c|c|c|c|c|c|c|}
\hline TDS & Station & May & June & July & August & September & October \\
\hline & Katsina & -0.06 & -0.02 & -0.01 & -0.24 & -0.19 & -0.20 \\
\hline & Sokoto & -0.30 & -0.13 & 0.01 & -0.23 & -0.19 & -0.25 \\
\hline & Nguru & -0.09 & -0.10 & -0.18 & -0.18 & -0.36 & -0.28 \\
\hline & Dutse & 0.08 & -0.30 & 0.08 & -0.28 & -0.06 & -0.20 \\
\hline & Gusau & 0.02 & 0.03 & -0.20 & -0.02 & 0.00 & -0.18 \\
\hline & Kano & 0.11 & -0.31 & 0.04 & -0.26 & -0.06 & -0.18 \\
\hline & Maiduguri & -0.05 & -0.11 & -0.34 & -0.27 & -0.05 & -0.17 \\
\hline & Potiskum & -0.21 & -0.16 & 0.04 & -0.22 & -0.17 & -0.20 \\
\hline & Zaria & -0.09 & -0.17 & -0.05 & 0.16 & -0.21 & -0.33 \\
\hline & Yelwa & -0.16 & -0.04 & 0.03 & -0.09 & -0.29 & -0.34 \\
\hline & Kaduna & -0.04 & -0.13 & 0.15 & 0.09 & 0.05 & -0.15 \\
\hline & Bauchi & 0.09 & 0.02 & 0.01 & -0.12 & -0.08 & -0.15 \\
\hline & Gombe & 0.29 & 0.28 & 0.37 & 0.03 & -0.08 & -0.17 \\
\hline \multirow[t]{13}{*}{ MxDS } & Katsina & -0.03 & -0.10 & 0.11 & -0.03 & -0.08 & -0.20 \\
\hline & Sokoto & -0.15 & -0.12 & -0.02 & -0.10 & -0.17 & -0.21 \\
\hline & Nguru & 0.02 & -0.19 & -0.03 & -0.17 & -0.21 & -0.33 \\
\hline & Dutse & 0.11 & -0.36 & 0.17 & -0.19 & -0.03 & -0.18 \\
\hline & Gusau & -0.05 & -0.09 & -0.09 & -0.06 & -0.07 & -0.15 \\
\hline & Kano & 0.13 & -0.38 & 0.08 & -0.14 & -0.03 & -0.18 \\
\hline & Maiduguri & -0.14 & -0.07 & -0.38 & -0.23 & 0.02 & -0.21 \\
\hline & Potiskum & -0.13 & -0.33 & 0.18 & -0.13 & 0.13 & -0.16 \\
\hline & Zaria & -0.03 & -0.15 & -0.01 & 0.07 & -0.06 & -0.21 \\
\hline & Yelwa & -0.11 & -0.08 & -0.02 & -0.28 & -0.38 & -0.26 \\
\hline & Kaduna & -0.16 & 0.00 & 0.26 & 0.06 & 0.05 & -0.25 \\
\hline & Bauchi & -0.09 & 0.09 & 0.06 & -0.11 & 0.09 & -0.15 \\
\hline & Gombe & -0.07 & 0.18 & 0.40 & -0.06 & -0.08 & -0.21 \\
\hline \multirow[t]{13}{*}{ MDS } & Katsina & -0.06 & -0.13 & 0.02 & -0.22 & 0.00 & -0.22 \\
\hline & Sokoto & -0.23 & -0.13 & 0.01 & -0.19 & -0.12 & -0.24 \\
\hline & Nguru & -0.09 & -0.19 & -0.12 & -0.17 & -0.25 & -0.32 \\
\hline & Dutse & 0.10 & -0.30 & 0.18 & -0.31 & -0.10 & -0.20 \\
\hline & Gusau & -0.03 & -0.06 & -0.13 & -0.08 & -0.04 & -0.20 \\
\hline & Kano & 0.13 & -0.34 & 0.09 & -0.21 & -0.10 & -0.17 \\
\hline & Maiduguri & -0.13 & -0.09 & -0.28 & -0.19 & -0.09 & -0.21 \\
\hline & Potiskum & -0.24 & -0.17 & 0.15 & 0.00 & -0.01 & -0.16 \\
\hline & Zaria & 0.01 & -0.14 & 0.01 & 0.05 & -0.13 & -0.22 \\
\hline & Yelwa & -0.14 & -0.12 & 0.04 & -0.29 & -0.28 & -0.33 \\
\hline & Kaduna & -0.10 & 0.02 & 0.30 & 0.09 & 0.11 & -0.15 \\
\hline & Bauchi & 0.11 & 0.08 & -0.04 & -0.08 & -0.04 & -0.21 \\
\hline & Gombe & 0.27 & 0.23 & 0.50 & 0.04 & -0.10 & -0.28 \\
\hline \multirow[t]{12}{*}{ FDS } & Katsina & 0.06 & 0.14 & -0.06 & 0.23 & -0.06 & 0.23 \\
\hline & Sokoto & 0.22 & 0.12 & -0.03 & 0.10 & 0.06 & 0.25 \\
\hline & Nguru & 0.11 & 0.24 & 0.07 & 0.14 & 0.17 & 0.38 \\
\hline & Dutse & -0.11 & 0.30 & -0.29 & 0.29 & 0.16 & 0.22 \\
\hline & Gusau & 0.05 & 0.08 & 0.07 & 0.00 & 0.17 & 0.20 \\
\hline & Kano & -0.13 & 0.34 & -0.18 & 0.11 & 0.16 & 0.19 \\
\hline & Maiduguri & 0.19 & 0.10 & 0.23 & 0.03 & 0.07 & 0.25 \\
\hline & Potiskum & 0.27 & 0.15 & -0.23 & -0.13 & -0.05 & 0.13 \\
\hline & Zaria & -0.05 & 0.08 & -0.11 & 0.09 & 0.03 & 0.20 \\
\hline & Yelwa & 0.13 & 0.15 & 0.00 & 0.33 & 0.11 & 0.33 \\
\hline & Kaduna & 0.14 & -0.08 & -0.25 & 0.02 & -0.09 & 0.19 \\
\hline & Bauchi & -0.13 & -0.08 & 0.02 & 0.01 & 0.00 & 0.23 \\
\hline
\end{tabular}


Table 2 (continued)

\begin{tabular}{llllllll}
\hline TDS & Station & May & June & July & August & September & October \\
\hline & Gombe & $\mathbf{- 0 . 2 8}$ & -0.17 & $\mathbf{- 0 . 2 7}$ & -0.06 & 0.11 & $\mathbf{0 . 3 3}$ \\
\hline
\end{tabular}

Statistically significant trends $(a=0.05)$ are in bold

spells. Additionally, the sparse distribution of rain gauge stations used in this study could cause some uncertainty in the results; therefore, future studies are encouraged in this regard.

Acknowledgements The authors would like to acknowledge National Weather Forecasting and Climate Research Center, Nigerian Meteorological Agency (NiMet), for providing the data used in this research. We would also like to express our sincere gratitude to the three anonymous referees for their relevant comments that helped improve this work.

\section{Compliance with ethical standards}

Conflicts of interest The authors declare that they have no conflicts of interest.

\section{References}

1. Mashi SA, Dominic O, Ibrahim A (2019) Disaster risks and management policies and practices in Nigeria: a critical appraisal of the National Emergency Management Agency Act. Int J Disaster Risk Reduct 33:253-265. https://doi.org/10.1016/j.ijdrr .2018.10.011

2. Sanni M, Odekunle TO, Adesina FA (2012) Spatio-temporal variation of drought severity in the Sudano-Sahelian region of Nigeria: implications for policies on water management. In: Leal Filho W (ed) Climate change and the sustainable use of water resources. Springer, Berlin, pp 415-430

3. Kayode AJ, Francis OA (2012) Drought Intensities in the SudanoSahelian region of Nigeria. J Sustain Soc 1:88-95

4. Fabeku BB, Okogbue EC (2014) Trends in vegetation response to drought in Sudano-Sahelian part of Northern Nigeria. Atmos Clim Sci 04:569-588. https://doi.org/10.4236/acs.2014.44052

5. Shiru M, Shahid S, Alias N, Chung E-S (2018) Trend analysis of droughts during crop growing seasons of Nigeria. Sustainability 10:871. https://doi.org/10.3390/su10030871

6. Murtala M, Iguisi EO, Ibrahim AA et al (2018) Spatio-temporal analysis of drought occurrence and intensity in northwest zone of nigeria. Dutse J Pure Appl Sci 4:111-129

7. Hassan AG, Fullen MA, Oloke D (2019) Problems of drought and its management in Yobe State, Nigeria. Weather Clim Extrem 23:100192. https://doi.org/10.1016/j.wace.2019.100192

8. Ayanlade A, Ojebisi SM (2018) Climate variability and change in guinea savannah ecological zone, Nigeria: assessment of Cattle Herders' responses. Handbook of climate change resilience. Springer, Cham, pp 729-747

9. Ogungbenro SB, Morakinyo TE (2014) Rainfall distribution and change detection across climatic zones in Nigeria. Weather Clim Extrem 5-6:1-6. https://doi.org/10.1016/j.wace.2014.10.002

10. Buba LF, Kura NU, Dakagan JB (2017) Spatiotemporal trend analysis of changing rainfall characteristics in Guinea Savanna of Nigeria. Model Earth Syst Environ 3:1081-1090. https://doi. org/10.1007/s40808-017-0356-2
11. Ayanlade A, Radeny M, Morton JF, Muchaba T (2018) Rainfall variability and drought characteristics in two agro-climatic zones: an assessment of climate change challenges in Africa. Sci Total Environ 630:728-737. https://doi.org/10.1016/j.scito tenv.2018.02.196

12. Obarein OA, Amanambu AC (2019) Rainfall timing: variation, characteristics, coherence, and interrelationships in Nigeria. Theor Appl Climatol 137:2607-2621. https://doi.org/10.1007/ s00704-018-2731-y

13. Umar AT, Mashi SA, Bako MM (2019) Investigation of rainfall characteristics in Sudano-Sahelian Region of Nigeria (19712006). Handbook of climate change resilience. Springer, Cham, pp 2595-2621

14. Odekunle TO (2004) Rainfall and the length of the growing season in Nigeria. Int J Clim 24:467-479. https://doi.org/10.1002/ joc. 1012

15. Gbode IE, Adeyeri OE, Menang KP et al (2019) Observed changes in climate extremes in Nigeria. Meteorol Appl 26:642-654. https ://doi.org/10.1002/met.1791

16. Gbode IE, Akinsanola AA, Ajayi VO (2015) Recent changes of some observed climate extreme events in Kano. Int J Atmos Sci 2015:1-6. https://doi.org/10.1155/2015/298046

17. Sanogo S, Fink AH, Omotosho JA et al (2015) Spatio-temporal characteristics of the recent rainfall recovery in West Africa. Int J Climatol 35:4589-4605. https://doi.org/10.1002/joc.4309

18. Odoulami RC, Akinsanola AA (2018) Recent assessment of West African summer monsoon daily rainfall trends. Weather 73:283287. https://doi.org/10.1002/wea.2965

19. Mohammed M, Abdulhamid A, Badamasi M, Ahmed M (2015) Rainfall dynamics and climate change in Kano, Nigeria. J Sci Res Rep 7:386-395. https://doi.org/10.9734/JSRR/2015/17098

20. Abaje IB, Patience J, Matazu M (2018) Spatio-temporal analysis of rainfall distribution in Kaduna State, Nigeria. Ghana J Geogr 10:1-21. https://doi.org/10.4314/gjg.v10i1.1

21. Umar AT, Bako MM (2019) Recent rainfall trends and variability in Sudano-Sahelian region of Nigeria (1986-2015). Ghana J Geogr 11:33-57. https://doi.org/10.4314/gjg.v11i1.3

22. Usman M, Nichol JE, Ibrahim AT, Buba LF (2018) A spatiotemporal analysis of trends in rainfall from long term satellite rainfall products in the Sudano-Sahelian zone of Nigeria. Agric For Meteorol 260-261:273-286. https://doi.org/10.1016/j.agrfo rmet.2018.06.016

23. Abiodun BJ, Lawal KA, Salami AT, Abatan AA (2013) Potential influences of global warming on future climate and extreme events in Nigeria. Reg Environ Change 13:477-491. https://doi. org/10.1007/s10113-012-0381-7

24. Shiru MS, Shahid S, Chung E-S et al (2019) A MCDM-based framework for selection of general circulation models and projection of spatio-temporal rainfall changes: a case study of Nigeria. Atmos Res 225:1-16. https://doi.org/10.1016/j.atmos res.2019.03.033

25. Bouagila $B$, Sushama $L$ (2013) On the current and future dry spell characteristics over Africa. Atmosphere (Basel) 4:272-298. https ://doi.org/10.3390/atmos4030272

26. Kebede A, Diekkrüger B, Edossa DC (2017) Dry spell, onset and cessation of the wet season rainfall in the Upper Baro-Akobo Basin, Ethiopia. Theor Appl Climatol 129:849-858. https://doi. org/10.1007/s00704-016-1813-y 
27. Byakatonda J, Parida BP, Kenabatho PK, Moalafhi DB (2019) Prediction of onset and cessation of austral summer rainfall and dry spell frequency analysis in semiarid Botswana. Theor Appl Climatol 135:101-117. https://doi.org/10.1007/s00704-017-2358-4

28. Sawa B, Adebayo A (2012) Effects of pentand dry spells on the yield of some crops in the semi-arid eco-climatic region of northern Nigeria. Zaria Geogr 19:49-60

29. Almazroui M, Balkhair KS, Islam MN, Şen Z (2017) Climate change impact on monthly precipitation wet and dry spells in arid regions: case study over Wadi Al-Lith basin. Adv Meteorol 2017:1-13. https://doi.org/10.1155/2017/5132895

30. Mathugama SC, Peiris TSG (2011) Critical evaluation of dry spell research. Int J Basic Appl Sci 11:153-160

31. Froidurot $S$, Diedhiou A (2017) Characteristics of wet and dry spells in the West African monsoon system. Atmos Sci Lett 18:125-131. https://doi.org/10.1002/asl.734

32. Lana X, Martínez MD, Burgueño A et al (2008) Spatial and temporal patterns of dry spell lengths in the Iberian Peninsula for the second half of the twentieth century. Theor Appl Climatol 91:99-116. https://doi.org/10.1007/s00704-007-0300-x

33. She D, Xia J (2013) The spatial and temporal analysis of dry spells in the Yellow River basin, China. Stoch Environ Res Risk Assess 27:29-42. https://doi.org/10.1007/s00477-011-0553-x

34. Huang J, Liu F, Xue Y, Sun S (2015) The spatial and temporal analysis of precipitation concentration and dry spell in Qinghai, northwest China. Stoch Environ Res Risk Assess 29:1403-1411. https://doi.org/10.1007/s00477-015-1051-3

35. Bibi U, Kaduk J, Balzter H (2014) Spatial-temporal variation and prediction of rainfall in Northeastern Nigeria. Climate 2:206222. https://doi.org/10.3390/cli2030206
36. Muita RR, Ogtrop FF Van, Vervoort RW (2012) Dry spell trend analysis in Kenya and the Murray Darling Basin using daily rainfall. Geophys Res 14

37. Wang XL (2008) Penalized maximal F test for detecting undocumented mean shift without trend change. J Atmos Ocean Technol 25:368-384. https://doi.org/10.1175/2007JTECHA982.1

38. Ogunrinde AT, Oguntunde PG, Olasehinde DA et al (2020) Drought spatiotemporal characterization using self-calibrating Palmer Drought Severity Index in the northern region of Nigeria. Results Eng 5:100088. https://doi.org/10.1016/j.rinen g.2019.100088

39. Lu GY, Wong DW (2008) An adaptive inverse-distance weighting spatial interpolation technique. Comput Geosci 34:1044-1055. https://doi.org/10.1016/j.cageo.2007.07.010

40. Kendall MG (1948) Rank correlation methods. Griffin, Oxford

41. Mann HB (1945) Nonparametric tests against trend. Econometrica 13:245. https://doi.org/10.2307/1907187

42. McLeod Al (2015) R Package 'Kendall.' 12

43. R Core Team (2019) R: a language and environment for statistical computing

44. Ibrahim I, Usman MT, Abdulkadir A, Emigilati MA (2018) Analysis of rainfall distribution, temporal trends, and rates of change in the Savannah Zones of Nigeria. Atmos Ocean. https://doi. org/10.1080/07055900.2018.1502149

Publisher's Note Springer Nature remains neutral with regard to jurisdictional claims in published maps and institutional affiliations. 